\title{
Climate Change and Peri-Urban Household Food Security-Lessons from West Taraka, Morobe Province, Papua New Guinea
}

\author{
Zina Bird and Linda Yuen
}

\begin{abstract}
Climate change has become a major concern towards the stability of global food production due to long and short-term climate related events. This paper will incorporate climate data to build on the existing data on the status of household food and nutrition security in one of Lae's peri-urban settlement, West Taraka in Morobe Province, Papua New Guinea. Two data sets were collected: household dietary patterns and changes in food production, and socio-economic characteristics, using stratified purposive sampling for selected fifty-eight (58) households in June 2016 through household survey and informal interviews (mixed method). Results show no statistical relationships between socio-economic characteristics of the households and their Household Dietary Diversity Score and Food Consumption Score. However, a significant inverse relationship at $95 \%$ probability exists between the numbers of household members in school with the Household Food Consumption Score. This study also found a significant positive relationship at $99 \%$ level probability between household income and Food Consumption Score signaling that income was the main determinant of household food and nutritional security.
\end{abstract}

Keywords Climate change $\cdot$ Food security $\cdot$ Household Food Consumption Score $\cdot$ Household Dietary Diversity Score - Papua New Guinea • Agriculture $\cdot$ Urbanisation

\section{Introduction: Global Context of Climate Change and Agriculture}

Climate change is a global phenomenon altering climate systems and having a wide range of impacts on human and natural systems. However, climate-related risks for

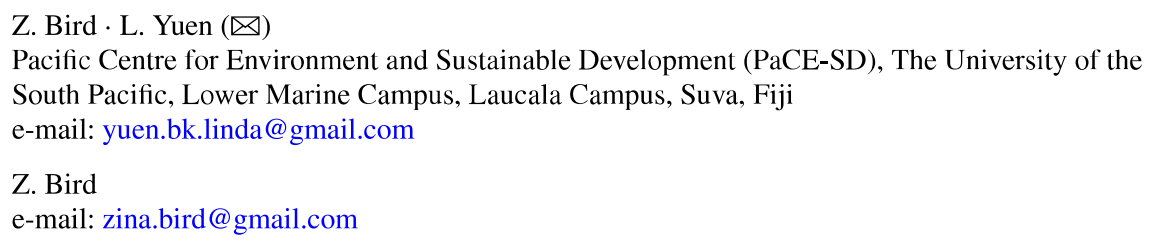


countries are unevenly distributed, with geographic location largely influencing the direction and rate of climatic change (IPCC 2018; Niles et al. 2017).

In agriculture or food system, it is recognized that climate and weather play a critical part towards food production and livelihoods (Niles et al. 2017). Various food crops require different stages or variation in weather conditions ( $\max$ and min temperature, rainfall/precipitation) and physical conditions (soil characteristic) for development, growth and yield. Because of the dependence on climate and the physical environment, it was stated by Rauff and Bello (2015), as temperature and carbon dioxide $\left(\mathrm{CO}_{2}\right)$ increases, it may affect the biological process of plants such as photosynthesis, growth, respiration, reproduction and the nutrient content in the soil. Although increase in $\mathrm{CO}_{2}$ and temperature can be beneficial for photosynthesis, it can also be harmful once the optimum range is exceeded and can reduce the amount of water content through the process of transpiration hindering the pores of the plants to open thus leading to a decline in yield or harvest (Rauff and Bello 2015).

For developing countries, including those of the Pacific islands region, that depend on agricultural production for socio-economic stability, declining crop production due to increase in temperature, change in precipitation pattern and introduction of new pest and diseases may have widespread negative impacts on food quality and safety (Niles et al. 2017). These biophysical factors also impacts the marine (aquaculture) and forestry systems.

For vulnerable Pacific Island countries, the impact of climate variability and extreme weather events such as flooding, drought, increase frequency of rain and cyclone result in significant loss of agricultural production (FAO 2018). Although farmers have developed and adopted potential methods to minimize climate related risk, the challenges to cope with the changes will still not be eliminated (Taylor et al. 2016). This increases the climate risk leading to increase in poverty in some population as global warming continues to increase affecting food security. Limiting warming to $1.5^{\circ} \mathrm{C}$ can reduce the number of people exposed to poverty and climate related risk by 2050 (IPCC 2018). Bogard et al. 2018 found relevant indicators to measure the strength and limitations of agricultural production, analyzing the nutritional yields, potential nutrient adequacy and Rao's quadratic entropy by capturing the ability of the production system that can nourish most people. These serve as useful tools for prioritizing agriculture-focused decision-making and policy-making in the public, private and civil society sectors. 


\section{Geography and Climate of PNG}

Papua New Guinea (PNG) is the largest of the Pacific small island developing states (PSIDS) and comprises the eastern half of the island of New Guinea and about 700 islands between the equator and $12^{\circ} \mathrm{S}$, and $140^{\circ} \mathrm{E}$ to $160^{\circ} \mathrm{E}$, in a region which is particularly prone to seismic activity. The population of 8.3 million is dispersed throughout a total landmass of $463,000 \mathrm{~km}^{2}, 74 \%$ of which is under forest cover (UNDP 2018). PNG's diverse terrestrial landscapes range from the montane rainforests of the Western Highlands to the Trans-Fly savanna and grasslands and from the mangrove swamps of the estuaries to the low-lying atolls. With over 800 distinct spoken languages, PNG is well known for being the most linguistically and culturally diverse place in the world, mainly attributed to geographical barriers hindering inter-tribal contact and interactions (Foley and Foley 1986).

Due to the proximity of PNG to the equator, there is little seasonal variation in atmospheric temperature across PNG and any significant variation is driven by changes in temperature of the sea surrounding the landmass. The southern regions experience a distinct wet season from November to April and a dry season from May to October. For example, Port Moresby receives an average annual rainfall of $1190 \mathrm{~mm}, 78 \%$ of which falls during the wet season. In comparison, seasonal rainfall variation is much weaker in the northern regions, where places like Kavieng receives as much as $3150 \mathrm{~mm}$ rainfall annually_almost three times more than in the southern regions. This is due to the northern region's proximity to the Western Pacific Warm Pool, which produces consistent rainfall throughout the year (BoM and CSIRO 2011). The montane rainforests of the Western Highlands receive an annual average of $7000 \mathrm{~mm}$ of rainfall (World Climate Guide 2019), further reflecting the uneven spatial distribution of rainfall across different regions of PNG.

The wide range in climatic conditions and physical landscapes have allowed PNG to support some of the world's most biologically diverse eco-regions. These conditions are also conducive to enabling the people of PNG to grow a wide range of food crops to meet their daily nutritional needs. Climate variables such as rainfall, temperature (air and sea), soil moisture and sea level directly affect plants development and yield. The increasing frequency and intensity of extreme climate events like frost, tropical cyclone and drought under current anthropogenic climate change is becoming a growing threat to crop production and food security (Wairiu et al. 2012; Weber 2014).

Although climate change is a global phenomenon, the impact in food security differs between regions. PNG is vulnerable to climatic extremes, such as frost, drought and flooding, which could cause poor crop harvests and increase food insecurity, poverty and disease (Bourke 2001). 


\section{Subsistence Agriculture}

Papua New Guinea's local economy is driven mainly by two sectors-(i) the mineral and energy extension sector, accountable for national export earnings, and (ii) the agriculture, forestry and fishery sector, mainly supporting the domestic subsistence economy (Gwatirisa et al. 2017).

Globally, 800 million people practice urban agriculture for basic consumption purposes (Game and Primus 2015; Lwasa et al. 2014). Similarly, for most PSIDS, agriculture is one of the most important sectors contributing towards the livelihoods, food security and gross domestic product (GDP) (Rosegrant et al. 2015; Taylor et al. 2016).

In PNG, the local agriculture sector supplies $83 \%$ of food energy and $76 \%$ of protein towards the country's nutritional needs (Bourke and Harwood 2009). It provides a safety net to rural and peri-urban communities in PNG, employing about half of the labour force and contributing 15\% towards GDP (ACIAR 2018). Most of the rural population is involved in producing most of their own staple foods and are also engaged in other forms of income earning activities to enable them to purchase foods which they do not produce themselves. Therefore, PNG can be generally considered as being food secure. However, some studies done in various locations in PNG (Bourke 2001; Bue 2013; Gwatirisa et al. 2017) have found that certain locations in the country are facing threats in household food and nutritional security. One such setting is the informal or peri-urban settlements which surround major urban centres of PNG. Vulnerable populations such as these have contributed to PNG's classification by FAO as a Low-Income Food-Deficit Country (LIFDC) (FAO 2015). Although PNG, on a national scale, produces enough of its own food, it is still facing malnutrition issues, exacerbated by social inequality and inadequate awareness on nutritional security and crop resilience.

In most of the informal peri-urban settlements that exist on the outskirts of PNG's major urban centres, public infrastructure and income-generating opportunities are often rudimentary, if available at all. The livelihoods of majority of the populations in these communities are centred on low wage employment and the informal sector (Umezaki and Ohtsuka 2003). With limited or no access to land for food gardening, households are heavily dependent on fresh food purchased from the local produce markets and store-bought processed food. The high cost of living in urban areas often force low income-earners to compromise their children's welfare and education in order to acquire just the basic staple foods for the household.

Like most Melanesian countries, most (97\%) of the land in PNG is under customary ownership (AusAID 2008). The State owns 2.5\% as public land while the remaining $0.5 \%$ is freehold land which can be privately owned by individuals. The development of customary land for commercial purposes is usually managed through Incorporated Land Groups (ILG), which in essence serves as a trust for individual landowning groups.

At $13.1 \%$, PNG currently has the lowest proportion of urban population among PSIDS, however, this is projected to rise to $24 \%$ by 2050 (UN DESA 2018). Rapid 
urbanisation, compounded by the impacts of climate change will make it increasingly difficult for urban and peri-urban populations meet basic household nutritional needs.

There is currently limited information on the relationship between climate change and household nutrition in PNG, particularly for informal settlements. This study aims to understand the status of household food and nutritional security of the West Taraka peri-urban settlement by profiling the selected socio-economic characteristics of households, examining the household dietary patterns and analysing the relationship between the two. The impact of climate change is also taken into consideration for this benchmark West Taraka study, which will potentially be a useful contribution to filling in the existing knowledge gap and to inform future policy-making processes from the community level up to the national level.

\section{The Study Site}

This study focuses on a typical peri-urban settlement-West Taraka, situated on the fringes of Lae City in the Morobe Province (Figs. 1 and 2).

The site was selected mainly for two reasons. Firstly, it is one of the project site of the Agriculture Department of the PNG University of Technology (Unitech) which conduct extension programmes to the community who farm the state agricultural land. Secondly, the site is close to Unitech and allowed easy access for the researcher to conduct the field survey.

West Taraka was initially established in 1974, on state residential land, by the PNG National Housing Commission (NHC) under the West Taraka Housing Scheme to provide low cost housing for civil servants, who later received the land titles. However, soon after the allocation of titles, titleholders began to subdivide and lease land to other people. Eventually, more people continued to move into the area and started illegally occupying the land around the demarcated Housing zone, which consists of a mixture of state reserved land, state agricultural land and customary land. Since its establishment, urban migration into West Taraka, mainly by rural migrants from the Highlands seeking employment opportunities in Lae City, has resulted in population growth rates even exceeding that of the main Lae City (Tapulu et al. 2014; Walsh 1987).

Although not officially categorised, West Taraka is generally considered a periurban settlement because it is located in the transition area between the urban boundary and the customary land. Urban agriculture is common practice for the community, utilising whatever little space available in the backyard of their homes to grow food for household consumption. Any excess produce is shared with neighbours and family or taken to be sold at the roadside markets. Sometimes people in the community are able to lease parcels of customary land from traditional landowners for a small fee or through informal arrangements. In this way, some household in West Taraka is able to have access to more space for crop production, both for household consumption and for selling at the local market. 


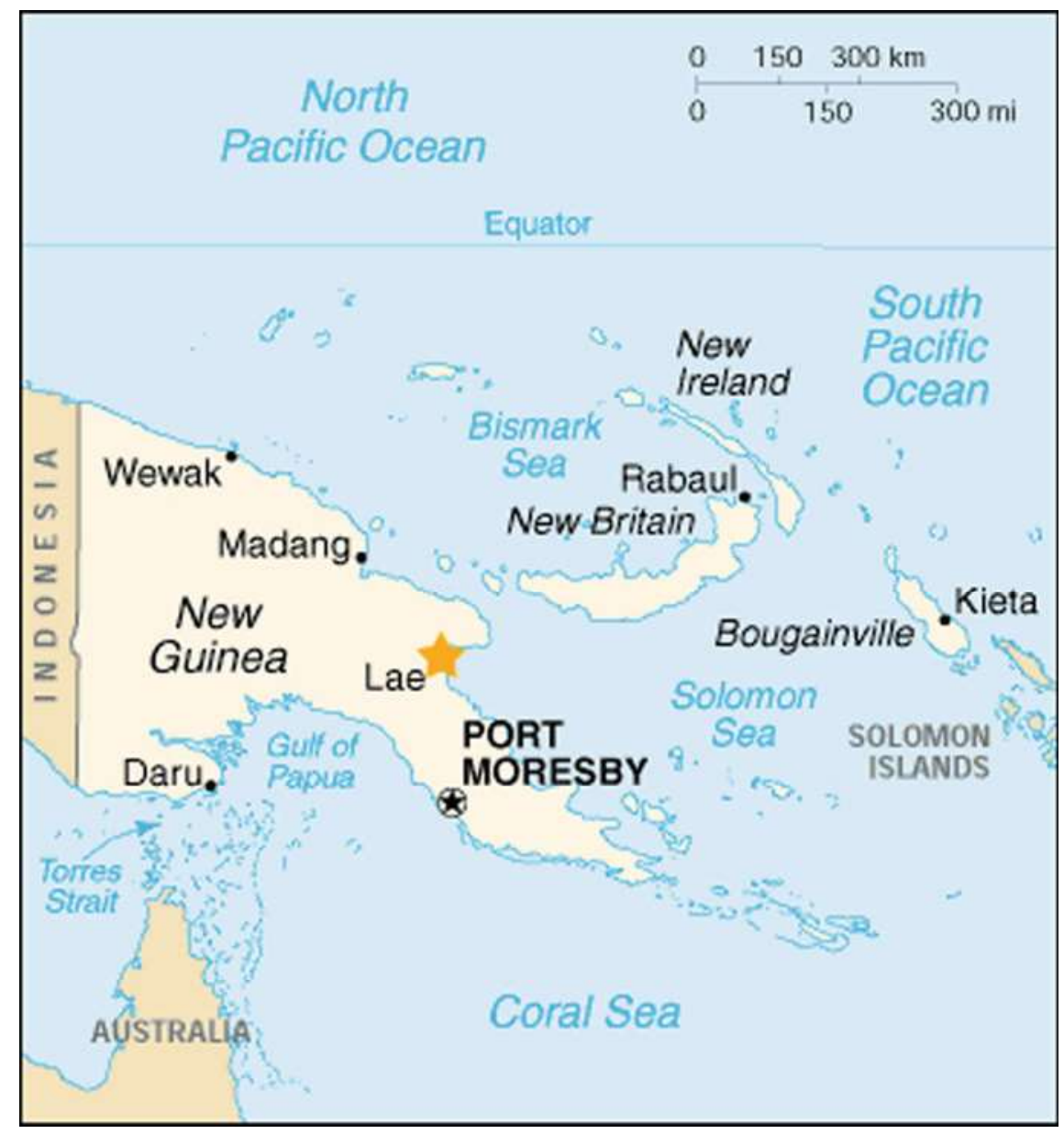

Fig. 1 Map of Papua New Guinea showing Lae City. Source http://www.justmaps.org/maps/ images/papua/lae-map1.gif

Lae's Nadzab Airport is the closest weather station to the site of this study. Rainfall records show that Lae receives almost $4500 \mathrm{~mm}$ of rainfall annually (Fig. 3) -an extraordinary amount which is distributed with only slight seasonal variation (PNG National Weather Service 2019). While high annual rainfall may provide favourable growing conditions for some crops, the increasing frequency of extreme rainfall events leading to severe flooding and soil erosion is problematic to the consistency of crop production.

Extreme climate events, such as tropical cyclone, flooding, drought and frost, affect squatter settlements disproportionately (United Nations Population Fund 


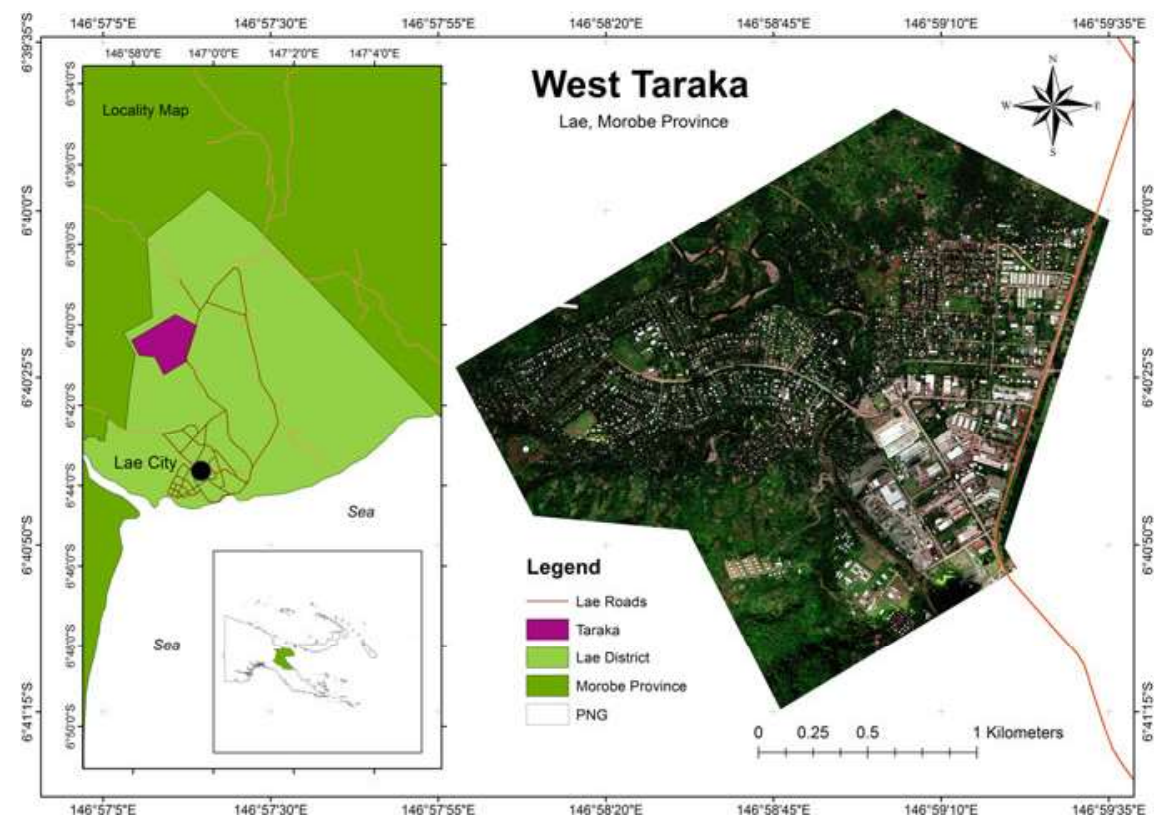

Fig. 2 Map showing location of the study site-West Taraka settlement (Tarutia 2019)

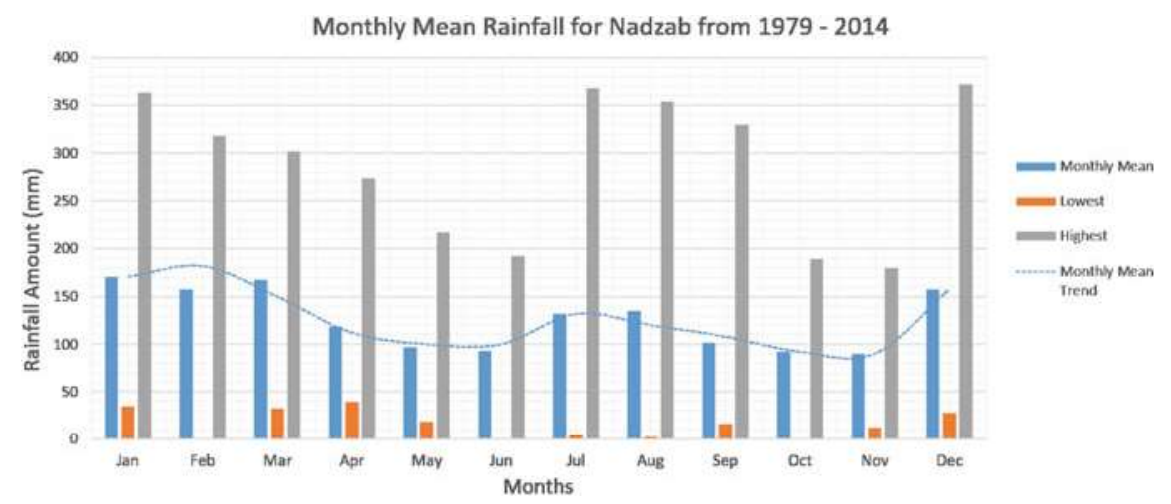

Fig. 3 Monthly rainfall for Lae (Nadzab Airport Station) (PNG National Weather Service 2019)

2007). The rapid growth and unmanaged land use (including unauthorized land clearance for backyard gardening) since the establishment of West Taraka were major factors which led to the disastrous September 1983 flooding event on the Bumbu River where 8 people were killed and hundreds of houses located along the river banks were destroyed (Atkins 2013). However, the scale of this disaster did not seem to deter the community from resuming its home gardening practices in order to produce food to meet household consumption needs. 


\section{Method}

\section{Sampling}

The 2-week field survey was conducted in June 2016. However because limited data was collected on climate change impact on food productions, literature review was used to relate how climate change influences the livelihoods of the West Taraka community.

Two sampling methods were used to select the sample population. First, stratified sampling was used to demarcate households based on the four land types found in West Taraka:

(i) state reserve land;

(ii) state residential land;

(iii) state agricultural land, and

(iv) customary land.

Stratification by land type was selected to assess the impact of accessibility to land for subsistence farming on household food consumption.

Research observation was also used during the survey, where the researcher recorded personal observation on the living conditions and the classification of the settlement. Peri-urban settlement was not a category in the 2011 PNG National Census, however it is classified as such in this survey because of the location of the settlement and its extension into other land areas.

Purposive sampling was then applied to select 4\% $(n=60)$ of 1500 households occupying West Taraka. While the sample size was initially 60 households, two of the households became unavailable halfway through the survey. Introducing new replacement households would increase the probability of bias created by the inaccuracy of results since the respondents would inevitably have difficulty in recalling food and drinks consumed in the prior week for the 24-h recall component. Thus, the survey continued with a sample size of 58 households.

\section{Assessment of Dietary Patterns-24-h Diet Recall}

Dietary patterns are the "quantities, proportions, variety or combinations of different foods and beverages in diets, and the frequency with which they are habitually consumed" (Rodgers 2015). At the household level, it is the consistent consumption of certain meal ingredients from different food groups by people living within the same dwelling.

The 24-h diet recall method was used previously in Bue (2013) and Koczberski et al. (2012) to capture the food security level in different regions in PNG. The meal components (ingredients, source and meal number) are measured using two

proxy, HDDS and FCS, which were developed for non-nutritionist to assess the 
status of food security without using anthropometric measurements (the size, shape and composition of the human body). These proxies have been found to be an efficient application to measure household nutritional quality in studies in Belgium, Burkina Faso, Mali, PNG and Bangladesh (Bue 2013; Savy et al. 2007; Torheim et al. 2004; Thorne-Lyman et al. 2009; Vandevijvere et al. 2010) and was therefore adopted in the survey.

\section{(a) Household Dietary Diversity Score (HDDS)}

The HDDS (scores ranging from 0 to 13) is the sum of food groups consumed within the last 24-h (FAO and USAID 360 2016; Swindale and Bilinsky 2006) and calculated for the duration of the 14-day survey. Instead of 12 food groups, 13 food groups was used. The 13 standard food groups (Bue 2013) used corresponds to specific meal ingredient, meal source and total meal consumed.

HDDS is also used as an indicator to measure the economic stability of a household. The number of food groups consumed is an indicator of household's purchasing power to access various food groups for a quality diet and nutritional security, thus, the higher the HDDS, the more money the household has to purchase different foods.

(b) Food Consumption Score (FCS)

FCS was calculated using the 24-h diet recall for the 14-day survey. Instead of using the normal 7-day frequency, a 14-day food recall was conducted to observe the diet trend for the households to establish if their diet is stable or fluctuating.

The FCS contains 9 food groups, however, 10 food groups were used for this survey (Bue 2013) which combines two food groups in the HDDS according to the given standard weight allocation based on its nutritional properties. The FCS measures the frequency of food over a period of time (7 days). The frequency of the food groups (per week) are multiplied by their given weights to calculate their nutritional value to obtained the FCS. The FCS is then used to determine the threshold of the households to indicate their level of food security. This proxy also allows the researcher to observe which food groups are consumed at a daily basis, giving the research an indication of the household's main staple food. In order to calculate the FCS, the formula used is: FCS $=$ food groups $\times$ weight. Each of the food groups (10) are multiplied with their own nutritional score to obtained the FCS.

People in West Taraka are engaged in a range of economic activities, including formal employment in public or private sectors, industries and self-employment. Household food consumption will inevitably be linked to household earnings, frequency of income and amount of harvest from food gardens. Therefore comparing the 14 days will give a good indicator of their diet pattern by analyzing the total frequency of foods consumed each day over the duration of the survey. 
(i) FCS thresholds

The FCS threshold was calculated to determine the nutritional profile of the households. Under this method, the researcher has the flexibility to use their own background knowledge on the type of staple foods consumed in the site and the consumption pattern to modify the FCS thresholds in order to produce the household nutritional profiles (Swindale and Bilinsky 2006).

The first profile for West Taraka was calculated to be the FCS range of 2332 , based on evidence that meals consisted mainly of cereal/tuber (rice and/or root crops), banana with green leafy vegetables cooked in coconut milk or oil, and tinned fish/meat and sugared tea. These are food groups consumed as the households' main staple. This finding agreed with Bue (2013) and Gwatirisa et al. (2017) who identified similar dietary patterns. The consumption of food groups for 3 or more days was considered as the main staple food to calculate the first threshold.

The second threshold of 32.5-40, consisted of all food groups in the first threshold, with the addition of fresh fish/chicken/meat in the calculation. Finally, the third threshold consisted of all 10 food groups, producing scores of over 40.

These thresholds are calculated based on the observed diet pattern during the 2-week survey.

\section{Assessment of Socio-Economic Level}

Eight household socio-economic characteristics were surveyed through interviews in West Taraka. These are:

(1) Age of head of household;

(2) Highest education level of head of household;

(3) Current occupation of head of household;

(4) Household size;

(5) Number of dependents attending school;

(6) Number of household members employed in the formal sector;

(7) Number of household members employed in the informal sector; and

(8) Total household income per fortnight.

Households occupying informal settlements around major urban centres generally have a lower level of engagement in the formal economy, a lower number of income earners and generate lower combined household income (Barber 2003), which all affect the ability to meet basic nutritional security. This assessment is used to determine whether there is a similar relationship between household socio-economic level and dietary patterns in West Taraka. 


\section{Data Analysis}

Description analysis method was used to analyze the percentage, mean, standard deviation, frequency and correlation coefficient test to explore the relationships between basic data collected during the survey and interviews. The analysis involves the use of Microsoft (MS) Excel and Statistical Package for the Social Sciences (SPSS).

\section{Results and Discussion}

\section{Household Characteristic Profile}

Eight socio-economic characteristics of the study site are presented in Table 1. It was found that the mean age for household heads was 48 years. Over half of the household heads are literate, $29 \%$ have reached secondary school, $23 \%$ completed their tertiary levels while $31 \%$ have completed primary school to Grade 8 level. Primary school completion is the most common education level attained in the rural community in the highlands of PNG (Schmidt et al. 2019). The level of literacy also corresponded with the engagement in wage employment by $59 \%$ of household heads who are involved in some form of wage/salary employment. Although $17 \%$ of the household heads are illiterate, only $12 \%$ are unemployed, either due to old age or unable to find employment. However, some of the unemployed household head are engaged in income generating activities such as farming on state agricultural land, backyard gardening and operating roadside stalls selling buai (betel nut or Areca nut), tobacco or cooked food. Majority of the households $(86 \%)$ have at least one dependent child in school. Some had over 4 children attending school.

According to field observation, differences in housing structures can be associated with the household's social status, similar to findings in Khan (2014). It was found that $62 \%$ of households consisted of at least 5 members while $38 \%$ consisted 4 or less members. While the average household size of 5 members in the study site, corresponds with PNG's national average, this is lower than the average size of households in Lae District (6.8 members) (PNG National Statistical Office 2011).

From the analysis, it was found that having a large family in a low socio-economic condition has largely negative impacts on the family's well-being. The impacts are exacerbated by limited land accessibility for gardening and other social constraints. Kiran and Dhawan (2015) found that larger households tends to have a wider range of expenses (such as school fees, stationeries, and other necessities) to cater to the needs of non-working dependents. Therefore, income diversion was a problem for the households, particularly for low income earners with large family members, making it difficult to accumulated savings.

The survey found that maximum income earned by the households fluctuated during the two weeks especially for those involved in the informal sectors. The income ranged from $\mathrm{K} 45.00$, for those involved in non-farming activities, to $\mathrm{K} 7800.00$, for 
Table 1 Household characteristic profile $(\mathrm{n}=58)$

\begin{tabular}{|c|c|c|c|c|c|c|c|}
\hline Characteristic & Range & $\begin{array}{l}\text { Measuring } \\
\text { unit }\end{array}$ & Category & Frequency & $\%$ & Mean & SD \\
\hline \multirow{3}{*}{$\begin{array}{l}\text { Age of Hh } \\
\text { heads }\end{array}$} & \multirow[t]{3}{*}{$25-80$} & \multirow[t]{3}{*}{ Years } & $25-35$ & 11 & 19 & \multirow[t]{3}{*}{48} & \multirow[t]{3}{*}{13} \\
\hline & & & $36-50$ & 27 & 47 & & \\
\hline & & & Above 50 & 20 & 35 & & \\
\hline \multirow{4}{*}{$\begin{array}{l}\text { Education } \\
\text { level of } \mathrm{Hh} \\
\text { heads }\end{array}$} & \multirow[t]{4}{*}{$0-13$} & \multirow[t]{4}{*}{ Grades } & Illiterate & 10 & 17 & \multirow[t]{4}{*}{8} & \multirow[t]{4}{*}{5} \\
\hline & & & $\begin{array}{l}\text { Primary } \\
(3-8)\end{array}$ & 18 & 31 & & \\
\hline & & & $\begin{array}{l}\text { Secondary } \\
(9-12)\end{array}$ & 17 & 29 & & \\
\hline & & & $\begin{array}{l}\text { Tertiary } \\
\text { (Above 12) }\end{array}$ & 13 & 23 & & \\
\hline \multirow{3}{*}{$\begin{array}{l}\text { Occupation } \\
\text { of Hh heads }\end{array}$} & \multirow[t]{3}{*}{-} & \multirow[t]{3}{*}{ Employment } & None & 7 & 12 & \multirow[t]{3}{*}{-} & \multirow[t]{3}{*}{-} \\
\hline & & & Formal & 34 & 59 & & \\
\hline & & & Informal & 17 & 29 & & \\
\hline \multirow[t]{3}{*}{ Family size } & \multirow[t]{3}{*}{$2-10$} & \multirow[t]{3}{*}{$\begin{array}{l}\text { Number of } \\
\text { members }\end{array}$} & $\begin{array}{l}\text { Small } \\
\text { (Up to 4) }\end{array}$ & 22 & 38 & \multirow[t]{3}{*}{5} & \multirow[t]{3}{*}{1} \\
\hline & & & $\begin{array}{l}\text { Medium } \\
(5-7)\end{array}$ & 30 & 52 & & \\
\hline & & & $\begin{array}{l}\text { Large } \\
\text { (Above 7) }\end{array}$ & 6 & 10 & & \\
\hline \multirow{4}{*}{$\begin{array}{l}\text { Dependents } \\
\text { in school }\end{array}$} & \multirow[t]{4}{*}{$0-6$} & \multirow{4}{*}{$\begin{array}{l}\text { Number of } \\
\text { dependents }\end{array}$} & None & 8 & 14 & \multirow[t]{4}{*}{2} & \multirow[t]{4}{*}{2} \\
\hline & & & Up to 2 & 31 & 54 & & \\
\hline & & & $3-4$ & 13 & 22 & & \\
\hline & & & Above 4 & 6 & 10 & & \\
\hline \multirow{2}{*}{$\begin{array}{l}\text { Hh members } \\
\text { employed in } \\
\text { the formal } \\
\text { sector }\end{array}$} & \multirow[t]{2}{*}{$0-4$} & \multirow{2}{*}{$\begin{array}{l}\text { Number of } \\
\text { members }\end{array}$} & None & 29 & 50 & \multirow[t]{2}{*}{-} & \multirow[t]{2}{*}{-} \\
\hline & & & Employed & 29 & 50 & & \\
\hline \multirow{2}{*}{$\begin{array}{l}\text { Hh members } \\
\text { employed in } \\
\text { the informal } \\
\text { sector }\end{array}$} & \multirow[t]{2}{*}{$0-2$} & Number of & None & 31 & 53 & - & - \\
\hline & & & Employed & 27 & 47 & & \\
\hline Total Hh & $45-7800$ & Kina & Up to 500 & 22 & 38 & 1160 & 1460 \\
\hline fortnightly & & & $501-1000$ & 17 & 29 & & \\
\hline & & & $1001-1500$ & 8 & 14 & & \\
\hline & & & $\begin{array}{l}\text { Above } \\
1500\end{array}$ & 11 & 19 & & \\
\hline
\end{tabular}


households with small businesses. It was also noted that 1 member in 7 households earned income for the whole family, this shows the economic constraints families faced. This data confirms other findings like Barber (2003) that the higher the number of household members working, the higher the combined household income, thus determining the HDDS and FCS. However, the $38 \%$ of households that earn below K500 has to improvise or prioritise spending, which often leads to sacrificing main meals per day.

\section{Change in Food Production}

During the 2015 frost and drought event in the Highlands region, main staple crops such as the sweet potato (kaukau), taro and yam took take up to nine months of growth before reaching maturity, compared to the usual six months. Inadequate technology in agricultural recovery after extreme climate events have resulted in food insecurity remaining as a major concern in the country. The frost event was the worst to affect the PNG Highlands region in 40 years and caused food severe food shortage for about 300,000 people (Cobon et al. 2016). International emergency response was activated to distribute food supplies to meet the basic nutritional needs of the communities affected (IOM 2016), illustrating the severity of the impacts of climate change and extreme climate events on food security to the vulnerable communities.

As peri-urban settlements expanded, farming activities decline. Majority of the foods consumed in PNG are locally produced, contributing to the high food security in rural areas due to availability of land resources for food production (Bourke 2001; Schmidt et al. 2019). However, it was reported that many villagers and settlements in PNG still remain vulnerable to food shortage due to extreme drought (El Niño) and severe frosting in the high altitudes (Kanua et al. 2016). Decline in crop production also disrupts supply to various markets in PNG, including Lae Market Centre, and may lead to temporary food shortage.

Agricultural productivity is sensitive to physical variables such as local weather conditions, soil nutrient status, moisture level and temperature. PCCSP climate projections for PNG, indicate with very high confidence, that sea surface temperature, atmospheric temperature, seasonal mean rainfall and annual rainfall are all likely to continue increasing throughout the 21st century (BoM and CSIRO 2011). Increase in temperature reduces the efficiency of photosynthesis, and as the long-term average local temperature increases beyond the upper threshold $\left(25^{\circ} \mathrm{C}\right)$ of the optimum range, most tropical crops like sweet potato, taro, cassava, and yams are directly affected (SPREP, n.d.). Survey respondents indicated that their food consumption level either declined or remain unchanged during the year (2015-2016). There was no incidence of increased household food consumption.

A total of 34 households (58.6\%) who are involved in home gardening also experience a decline in production from both social and environmental impacts which led to increased dependence on processed food. Table 2 represents a summary of the respondents' perceptions to explain the experienced decline in food production. 
Table 2 Household response on the impact on crop production

\begin{tabular}{l|l}
\hline Social impact & Environmental/climate change impact \\
\hline $\begin{array}{l}\text { Customary land } \\
\begin{array}{l}\text { Hh has to ask for permission to cultivate in } \\
\text { their land and pay certain fees given by the } \\
\text { owners }\end{array}\end{array}$ & $\begin{array}{l}\text { Drought } \\
\text { Loss of crops, water/irrigation }\end{array}$ \\
\hline Thief & $\begin{array}{l}\text { Rainfall } \\
\text { Flooding due to the location of the settlement } \\
\text { and poor drainage system }\end{array}$ \\
\hline $\begin{array}{l}\text { Agricultural land } \\
\text { Was assigned to certain person thus not all } \\
\text { have the accessibility }\end{array}$ & $\begin{array}{l}\text { Frost } \\
\text { For Hh's with farms in the interior part of } \\
\text { PNG }\end{array}$ \\
\hline $\begin{array}{l}\text { Labour force } \\
\text { Most Hh members are working either in the } \\
\text { formal or informal sector }\end{array}$ & $\begin{array}{l}\text { Temperature } \\
\text { Increase in heat affecting the time spend in the } \\
\text { gardens }\end{array}$ \\
\hline $\begin{array}{l}\text { Hh heads } \\
\text { Hh heads (female) have limited support to } \\
\text { help out in the garden due to old age or } \\
\text { members are children }\end{array}$ & \\
\hline \begin{tabular}{l} 
Overcrowding in the area \\
\hline
\end{tabular} & \\
\hline
\end{tabular}

Majority of households attributed crop decline mainly to a range of social impacts, with only a few highlighting the impacts of environmental changes. A recent study on the impacts of the 2015 drought in PNG (Gwatirisa et al. 2017), found that while many participants were unable to give a clear recollection of when the drought started, they agreed that it would have a lasting effect on their livelihoods. It indicated that while local farmers were able to identify the impacts on crops, they have little adaptation mechanism to cope. In comparison, respondents in West Taraka mainly attributed social factors rather than environmental and climate change on declining crop production.

\section{Household Dietary Diversity and Food Consumption Scores}

\section{$H D D S$}

Analysis on meal characteristics (Table 3) indicate that majority of households only consumed 2 meals (breakfast and dinner) on a daily basis, which reflects similar patterns for oil palm farmers in Madang Province and West New Britain Province (Bue 2013; Nahuet and Bue 2015).

Two main factors that influence household diet were income and family size. This indicates that the households reduced their meal spending to cater for the children's school fees. 
Analysis of the households' meal sources (Fig. 4) found that 59\% of foods were bought from the store, $23 \%$ from the market, $14 \%$ from own garden, $3 \%$ were shared among households and $1 \%$ from friend's garden. This indicates that majority of the households depended on processed foods which also confirms previous studies (Bourke 2001; Gwatirisa et al. 2017; Koczberski et al. 2012; Nahuet 2014; Nahuet and Bue 2015; Yamauchi et al. 2001). This shows that while store-bought food usually makes up a larger portion of household food sources in urban centres, this trend is becoming more common in the rural and peri-urban areas as well.

Majority of the households' HDDS range from 1 to 8 food groups consumed and a mean of 5 food groups consumed daily, which technically meets the daily food consumption needs based on international guidelines (WHO 2003). However, the foods most commonly consumed in West Taraka are high in carbohydrate and low in other nutritional value. There is insufficient consumption of high vitamin and protein food groups, subjecting many households to the risk of malnutrition.

The average frequency of consumption of different food groups during a typical week is presented in Table 4. It was found that rice was consumed most frequently in West Taraka, with households consuming it 6 out of 7 days. In comparison, root crops such as kaukau (sweet potato) was only consumed 3 times a week, banana twice a week and cassava once a week. Tin fish (consumed 4 times a week) was substituted as a protein cooked with noodles ( 3 days per week), green leafy vegetables (6 days) cooked in coconut milk or oil (4 days per week).

Table 3 Number of meals consumed per day $(n=58)$

\begin{tabular}{l|l|l|l|l|l|l|l}
\hline Characteristic & Range & $\begin{array}{l}\text { Measuring } \\
\text { unit }\end{array}$ & Category & Frequency & Percent & Mean & SD \\
\hline $\begin{array}{l}\text { Number of } \\
\text { meals per day }\end{array}$ & $1-3$ & Meal & 1 & 3 & 5 & 2 & 0.6 \\
\cline { 3 - 6 } & & & 2 & 36 & 62 & & \\
\cline { 3 - 6 } & & 3 & 19 & 33 & & \\
\hline
\end{tabular}

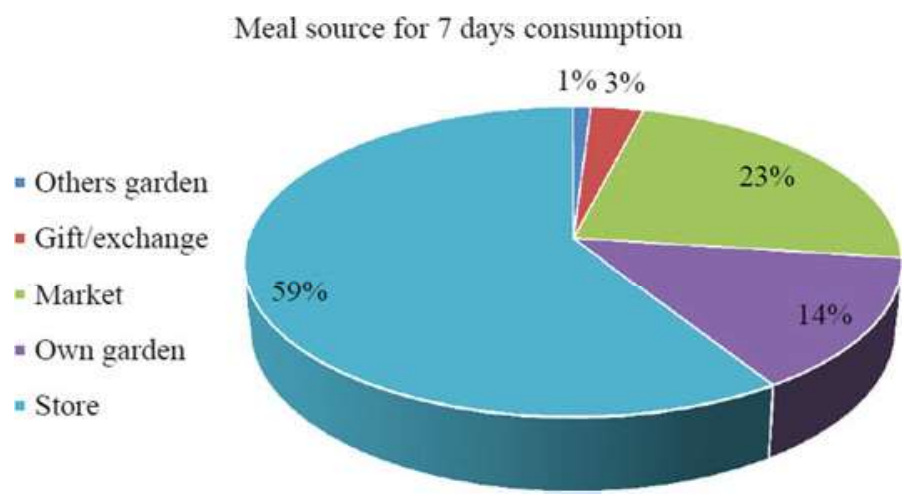

Fig. 4 Household meal sources for seven days 
Table 4 Average consumption of the specific foods and the collapsed food groups over a 7 day period

\begin{tabular}{l|l|l}
\hline Food Items & $\begin{array}{l}\text { Average consumption of specific } \\
\text { foods per week }\end{array}$ & $\begin{array}{l}\text { Average consumption of collapsed } \\
\text { food groups per week }\end{array}$ \\
\hline Banana & 2 & \\
\hline Kaukau & 3 & 7 \\
\hline Cassava & 1 & \\
\hline Rice & 6 & \\
\hline Noodle & 3 & \\
\hline Tin fish & 4 & 4 \\
\hline Tin meat & 1 & \\
\hline Pork & 0 & \\
\hline Beef & 0 & \\
\hline Chicken & 1 & 2 \\
\hline Sausage & 0 & \\
\hline Fish & 0 & 6 \\
\hline Lamb & 0 & 4 \\
\hline Egg & 0 &
\end{tabular}

Households in West Taraka are highly dependent on imported processed foods to make up their daily nutritional requirements. Low cost protein and fat substitutes such as tinned fish/meat and coconut cream are often consumed instead of the fresh options (Gwatirisa et al. 2017). 62\% of households consume 4-6 food groups daily, $14 \%$ consumed more than 6 groups while 24\% had less than 3 food groups-are falling below the basic daily food requirement leading to malnutrition. The trend of their diet within the 14 days shows little to no change in their dietary pattern. Results from this study supports studies done by Bourke (2001), Hodge et al. (1996), Yamauchi et al. (2001), Nahuet (2014), Koczberski et al. (2012) and Bue (2013). These studies all agreed that, due to limited access to gardening space, urban households tend to purchase most of their fresh foods from the markets and main staples from stores.

\section{FCS Threshold}

Based on the analysis, we calculated the FCS according to the observation and data collected for the 2 weeks based on which food groups were consumed more frequently for 7 days. From the frequencies, we identified the main staple foods which we used to calculate the threshold which was adjusted from the WFP guidelines. 
Although the FCS, which range from 23 to 61.5, did not present the household caloric intake of micro and macro nutrients, it was used to measure the household nutritional security or the nutritional profile. At the end of Week 1 of the survey (Fig. 5), 60\% of the households have high FCS and are nutritionally secure. The $26 \%$ of households on the borderline have either the potential to improve their diet or are risk of diet declining leading to lack of nutritional security. The $14 \%$ who have low FCS have a high risk of nutritional deficiency.

The analysis for Week 2 (Fig. 6) shows that there was only a slight difference in the FCS. $62 \%$ of the households showed high dietary consumption, however these are not the same households represented in Week 1 . Some of the households that were on the borderline in Week 1 actually improved their nutritional intake and moved

\section{Week 1 FCS Threshold}

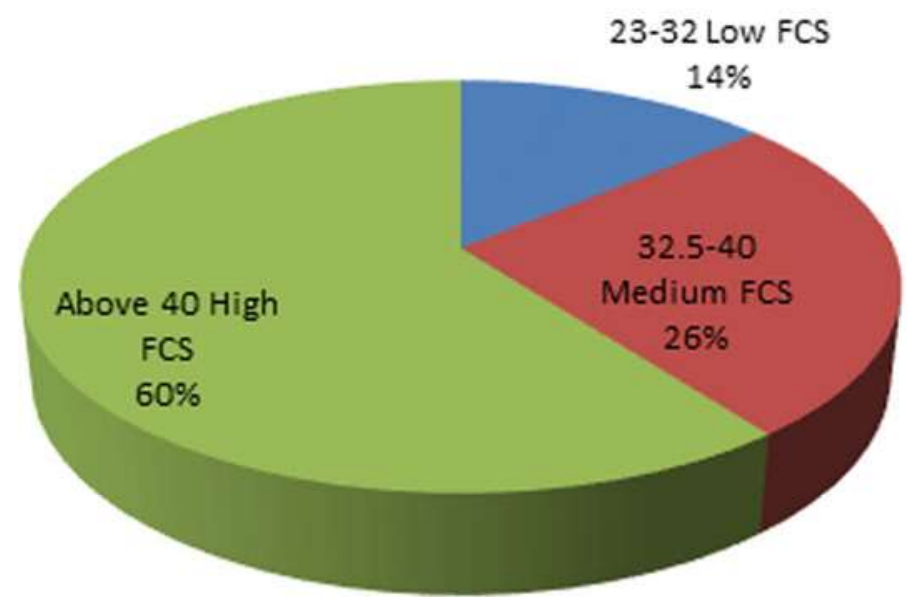

Fig. 5 Household FCS threshold for week 1

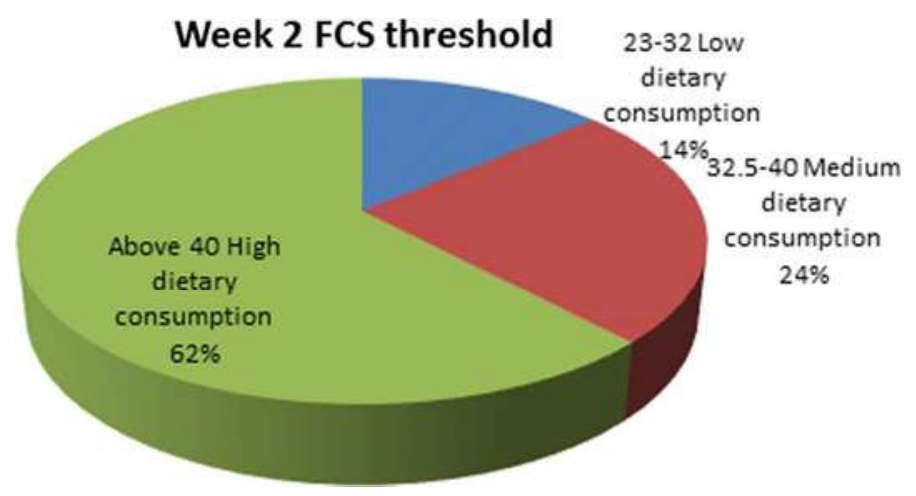

Fig. 6 Household FCS threshold for week 2 
up from the medium threshold to the high threshold in Week 2. The reason was that households not only depend on their income but also diversification of income earning activities to provide food. The finding also supports Bue (2013) and Koczberski et al. (2012) that fortnight and non-fortnight earnings and the fluctuation in oil palm price influenced the dietary patterns of the oil palm smallholder households.

\section{Correlation Test Between the Selected Socio-Economic Characteristics of the Households and Their FCS and HDD}

Previous studies have established a relationship between socio-economic characteristics and household dietary patterns (Drewnowski and Darmon 2008; Giskes et al. 2007; Murakami et al. 2009; Mirmiran et al. 2002; Rezazadeh et al. 2010; Lenz et al. 2009). Therefore, the 8 selected household socio-economic characteristics were correlated against HDDS and FCS to evaluate the presence of any similar statistical relationships. The results are presented in Table 5.

Out of the 8 household socio-economic characteristics, income showed the largest positive correlation with FCS (0.361 at 0.01 probability), indicating that as income

Table 5 Correlation coefficient between the socio-economic characteristics of the households and their FCS and HDDS $(\mathrm{n}=58)$

\begin{tabular}{l|l|l}
\hline \multirow{2}{*}{$\begin{array}{l}\text { Socio-economic characteristics of the } \\
\text { households }\end{array}$} & Independent variable & Correlation coefficient \\
\hline \multirow{2}{*}{ Age of Hh heads } & FCS & -0.051 \\
\cline { 2 - 3 } & HDDS & -0.046 \\
\hline \multirow{2}{*}{ Education level of Hh heads } & FCS & 0.19 \\
\cline { 2 - 3 } & HDDS & 0.128 \\
\hline \multirow{2}{*}{ Occupation of Hh heads } & FCS & 0.201 \\
\cline { 2 - 3 } & HDDS & 0.053 \\
\hline \multirow{2}{*}{ Family size } & FCS & -0.214 \\
\cline { 2 - 3 } & HDDS & 0.023 \\
\hline \multirow{2}{*}{ Dependents in school } & FCS & $-0.281^{*}$ \\
\cline { 2 - 3 } & HDDS & -0.124 \\
\hline \multirow{2}{*}{ Hh members employed in the formal sector } & FCS & 0.063 \\
\cline { 2 - 3 } & HDD & 0.063 \\
\hline \multirow{2}{*}{ Hh members employed in the informal sector } & FCS & 0.085 \\
\cline { 2 - 3 } & HDDS & -0.005 \\
\hline \multirow{2}{*}{ Total Hh fortnightly income } & FCS & $0.361^{* *}$ \\
\cline { 2 - 3 } & HDDS & 0.112 \\
\hline
\end{tabular}

${ }^{*}$ Significance at 0.05 level of probability

${ }^{* *}$ Significance at 0.01 level of probability 
increases, households were able to consume more food groups. The high income level is linked to formal employment opportunities and other income-generating activities that households are engaged in, thereby increasing purchasing power to access quality foods such as fresh meats (chicken, meat, fish egg and dairy products). In addition, households are able to consume more than one meal per day thus contributing to their high FCS. This significance was also found in other countries (González et al. 2008; Butt and Iram 2004; DeWalt 1983; Kirkpatrick and Tarasuk 2003) and in selected locations in PNG (Bue 2013; Nahuet and Bue 2015; Koczberski et al. 2012; Shack et al. 1990). The education level of household heads and their current occupation also have a positive correlation with FCS (0.190 and 0.201, respectively), indicating the ability of literate heads of household to engage in stable income-generating activities to provide for their families.

In comparison, a negative correlation of -0.281 at 0.05 level of probability was seen between the number of dependents who were in school and household FCS, indicating that as the number of children in school increases, the lower the household FCS. A similar inverse relationship was seen between the household size $(-0.214)$ and FCS. It is often more difficult for larger households to meet basic nutritional needs due to the diversity of expenses incurred to cater for the needs of non-income generating dependents such as school-aged children.

While this study did not separately evaluate the characteristics of mothers in the household, studies in Mozambique (Sahn and Alderman 1997; Garrett and Ruel 1999; Burchi 2012) have found significant positive relationships between FCS and the mothers' education level and knowledge in meal preparation. This shows mothers' awareness of the nutritional value of the meals they prepare that promotes nutritious benefit for their families.

Overall, this study confirms studies done by Amaza et al. (2008), Mueller et al. (2001), Drewnowski and Darmon 2008, Gwatirisa et al. (2017): Giskes et al. (2007), Murakami et al. (2009), Mirmiran et al. (2002); Rezazadeh et al. (2010) and Lenz et al. (2009) that the socio-economic factors of the households influences the households' dietary patterns, hence the household food and nutritional security.

\section{Conclusion, Limitations and Recommendations}

The population of the West Taraka peri-urban settlement has continued to grow as urban migration continue to increase, resulting in unauthorized settlements on both state and customary land. Few households are able to gain access to both customary and state land for food gardening unless they can afford to pay for a formal lease. This study was conducted to understand the status of household food and nutritional security in peri-urban settlements by profiling eight selected socio-economic characteristics, examining the household dietary patterns and analysing the relationship between the two. The sample population was identified through stratification by the four land types found within the study site and purposive sampling. Assessment of 
dietary patterns using the 24-h diet recall method from which two quantitative indicators, i.e. HDDS and FCS, were calculated for the 2-week survey. Pearson's correlation analysis was used to examine the relationship between the socio-economic characteristics and household food consumption.

The study found that $83 \%$ of the household heads are literate, corresponding with the $88 \%$ engagement in some form of employment- $59 \%$ in formal employment and $29 \%$ in the informal sector. Only $12 \%$ are unemployed and unable to generate any form of income, due to old age or retirement. Despite this, other household members are able to support the household in other ways, notably through crop gardening, which is practiced by $58.6 \%$ of the households.

Most households consume only 2 meals daily_-breakfast (before members leave the house) and dinner (when all members return home). Most of the meal ingredients are purchased either from the store (59\%) or from the local fresh produce market (23\%), while $14 \%$ were obtained from their own gardens. The remaining $4 \%$ were obtained through gifting and sharing of food, most commonly given by households that have access to farming space to those who do not. The food consumption score (FCS) for households in West Taraka ranged from 23 to 61.5, with $60 \%$ households found to be nutritionally secured, $26 \%$ on the borderline, and $14 \%$ at risk of nutritional insecurity.

Pearson's correlation analysis shows that there is a significant positive relationship between the FCS and income, indicating that income drives the consumption pattern of a household. Education level of household heads and their current occupation also have a positive correlation with FCS, indicating the ability of literate heads of household to engage in stable income-generating activities to provide for their families. While some households were faced severe economic constraints, they were able to maintain a basic diet. In comparison, a significant inverse relationship was found between FCS and the number of household members in school, indicating that expense diversification compromised the consumption of quality diets.

Previous studies have also established linkages between household diet and agriculture and highlighted the threat that climate change poses on community livelihoods (Cobon et al. 2016; Gwatirisa et al. 2017; IOM 2016). The 2015 drought and frost event which affected large populations in the PNG Highlands regions illustrated the threat of climate extremes to crop production and food security, particularly for vulnerable rural and peri-urban populations without adequate access to housing, land resources, income-generating opportunities and basic awareness of nutritional diets and climate change risks.

It may be necessary for people in West Taraka to diversify their income-generating activities in order to be able to meet their basic household nutritional needs. The growing influence of urbanization and limitations in access to farming space has resulted in transformation of the community's dietary patterns to a more processedfood diet. $90 \%$ of the local rural population in PNG derive their income from selling fresh foods (Bourke and Harwood 2009). Both temperature and rainfall are projected to increase over the 21st century in PNG, bringing increased frequency of extreme heat, extreme frost and severe rainfall events (BoM and CSIRO 2011). Crop 
production, both on a commercial and subsistence scale, have already been experiencing significant decline in PNG due to climate-related extreme events (IOM 2016). Rural and peri-urban communities will find it increasingly difficult to rely solely on agriculture-based activities to generate a stable level of household income. Households that rely on home gardening to meet their nutritional needs will face difficulty in producing enough food due to the increasingly hazardous climatic conditions, further jeopardising household food security.

Many PSIDS have shared development challenges and lessons learnt from country is often applicable to another. The challenges associated with urban sprawl, compounded with the pressures of complex land tenure systems and increasing threat of climate change inevitably affects the long-term food security of local communities. This research in PNG provides valuable lessons to guide other PSIDS in carrying out similar studies to build community resilience again climate change impacts.

\section{Limitations and Implications of the Study Site}

As the first household nutritional security study to be conducted in West Taraka, inferences and conclusions were drawn based on 58 households. The scope of this study was limited by the amount of research funding, duration of study, availability of households in the community, field assistance, challenges to personal safety at the study site and lack of recent nutritional data to support the findings in the study site.

There is a clear lack of awareness in climate change and household food security among the West Taraka community. The researchers recommend the prioritisation of awareness programmes for rural and peri-urban communities to empower people in making informed decisions for their household nutritional security under the exacerbating threats of climate change on crop production. The findings also contribute valuable information to the Ministry of Health's efforts in making effective policies to enhance national nutritional status for PNG.

The researchers recommend further studies to be conducted in the future to confirm the current findings, with particular focus on the impacts of environmental and climate change on food security and household diet. It would also be valuable to expand the sample size and survey duration, if adequate time, community assistance and financial resources are available. The enhanced study would contribute to filling the knowledge gap in understanding the perspectives of PNG peri-urban communities on the impacts of climate change on their livelihood, given the socio-economic and environmental constraints they face.

\section{References}

Australian Centre for International Agricultural Research [ACIAR] (2018) ACIAR. Annual Repot 2017-18. Canberra, Australia. ISBN 978-1-925746-53-2 (PDF/online) 
Amaza PS, Adejobi AO, Fregene T (2008) Measurement and determinants of food insecurity in northeast Nigeria: some empirical policy guidelines. J Food Agric Environ 6(2):92-96

Atkins GP (2013) Erosion and drainage problems in the environs of Lae: a disaster waiting to happen-again. In: Proceedings of the 7th Huon seminar-achieving vision 2050 though higher education, research, science and technology (13th-14th Nov 2013, Papua New Guinea University of Technology, Lae, PNG), p 92

AusAID (2008) Making land work: volume two - case studies on customary land and development in the Pacific. Australian Agency for International Development, Canberra

Bogard RJ, Mark CG, Thilsted S, Wood HS (2018) Measuring nutritional quality of agricultural production systems: application to fish production. Glob Food Secur 16:54-64

Barber K (2003) The Bugiau community at eight-mile: an urban settlement in Port Moresby, Papua New Guinea. Oceania 73(4):287-297

BoM (Australia) and CSIRO (2011) Papua New Guinea. Climate change in the Pacific: scientific assessment and new research. Volume 2: country reports, vol 2. Australian Bureau of Meteorology and Commonwealth Scientific and Industrial Research Organisation, Aspendale, VIC, pp 169184

Bourke RM (2001) An overview of food security in Papua New Guinea. Paper presented at the Proceedings of the Papua New Guinea food and nutrition 2000 conference, 26-30 June 2000, PNG University of Technology, Lae. https://ageconsearch.umn.edu/record/135368/files/PR099. pdf\#page $=19$

Bourke R, Harwood T (2009) Food and agriculture in Papua New Guinea

Bue VG (2013) The role of smallholder farmers in sustaining household food security at Bialla and Hoskins oil palm land settlement schemes, Papua New Guinea (Ph.D.), Curtin University

Burchi F (2012) Whose education affects a child's nutritional status? From parents' to household's education. Demographic Res 27:681-704

Butt MS, Iram U (2004) Determinants of household food security: an empirical analysis for Pakistan. Int J Soc Econ 31(8):753-766. https://doi.org/10.1108/03068290410546011

Cobon DH, Ewai M, Inape K, Bourke RM (2016) Food shortages are associated with droughts, floods, frosts and ENSO in Papua New Guinea. Agric Syst 145:150-164. https://doi.org/10.1016/ j.agsy.2016.02.012

DeWalt KM (1983) Income and dietary adequacy in an agricultural community. Soc Sci Med 17(23):1877-1886. https://doi.org/10.1016/0277-9536(83)90165-X

Drewnowski A, Darmon N (2008) Does social class predict diet quality? Am J Clin Nutr 87(5):11071117. https://doi.org/10.1093/ajen/87.5.1107

FAO (2015) Low-Income Food-Deficit Countries (LIFDC)—list for 2015. Retrieved 09 Sept 2016. http://www.fao.org/countryprofiles/lifdc/en/

FAO (2018) Asia and the Pacific regional overview of food security and nutrition 2018-accelerating progress towards the SDGs. Bangkok. License: CC BY-NC-SA 3.0 IGO

FAO and USAID (2016) Minimum dietary diversity for women - a guide to measurement. Food and Agriculture Organization of the United Nations and USAID's Food and Nutrition Technical Assistance III Project (FANTA), Rome, Italy, p 82

Foley WA, Foley WA (1986) The Papuan languages of New Guinea. Cambridge University Press

Game I, Primus R (2015) Urban Agriculture. State University of New York College of Forestry and Environmental Science

Garrett JL, Ruel MT (1999) Are determinants of rural and urban food security and nutritional status different? Some insights. World Dev 27(11):1955. https://doi.org/10.1016/S0305750X(99)00091-1

Giskes K, Turrell G, van Lenthe FJ, Brug J, Mackenbach JP (2007) A multilevel study of socioeconomic inequalities in food choice behaviour and dietary intake among the Dutch population: the GLOBE study. Public Health Nutr 9(1):75-83. https://doi.org/10.1079/PHN2005758

González W, Frongillo EA, Jiménez A, Madrigal G, Muñoz LM (2008) Development and validation of measure of household food insecurity in Urban Costa Rica Confirms proposed generic questionnaire. J Nutr 138(3):587-592. https://doi.org/10.1093/jn/138.3.587 
Gwatirisa PR, Pamphilon B, Mikhailovich K (2017) Coping with drought in Rural Papua New Guinea: a Western Highlands case study. Ecol Food Nutr 56(5):393-410. https://doi.org/10.1080/ 03670244.2017.1352504

Hodge AM, Montgomery J, Dowse GK, Mavo B, Watt T, Alpers MP, Zimmet PZ (1996) Diet in urban Papua New Guinea population with high levels of cardiovascular risk factors. Ecol Food Nutr 35:311-324

IOM (2016) Papua New Guinea drought and floods response: situation report. From: https:// reliefweb.int/sites/reliefweb.int/files/resources/IOM\%20Sitrep\%20\%238\%20\%20PNG\% 20Drought\%20\%28May\%202016\%29_v2.pdf

IPCC (2018) Summary for policymakers. In: Global warming of $1.5^{\circ} \mathrm{C}$. An IPCC special report on the impacts of global warming of $1.5^{\circ} \mathrm{C}$ above pre-industrial levels and related global greenhouse gas emission pathways, in the context of strengthening the global response to the threat of climate change, sustainable development, and efforts to eradicate poverty [V. Masson-Delmotte, P. Zhai, H. O. Pörtner, D. Roberts, J. Skea, P. R. Shukla,A. Pirani, W. Moufouma-Okia, C. Péan, R. Pidcock, S. Connors, J. B. R. Matthews, Y. Chen, X. Zhou, M. I. Gomis, E. Lonnoy, T. Maycock, M. Tignor, T. Waterfield (eds.)]. World Meteorological Organization, Geneva, Switzerland, $32 \mathrm{pp}$

Kanua M, Bourke RM, Jinks B, Lowe M (2016) Assessing village food needs following a natural disaster in Papua New Guinea. Church Partnership Program, The Australian Government Department of Foreign Affairs and Trade (DFAT), Canberra

Khan AA (2014) Analysis of housing structure in Peri Urban areas of Faisalabad, Pakistan. Asian J Multidisciplinary Stud 1(2):57-62

Kiran T, Dhawan S (2015) The impact of family size on savings and consumption expenditure of industrial workers: a cross-sectional study. Am J Econ Bus Adm 7(7):177-184

Kirkpatrick S, Tarasuk V (2003) The relationship between low income and household food expenditure patterns in Canada. Public Health Nutr 6(6):589-597. https://doi.org/10.1079/ PHN2003517

Koczberski G, Curry GN, Bue V (2012) Oil palm, food security and adaptation among smallholder households in Papua New Guinea. Asia Pac Viewpoint 53(3):288-299. https://doi.org/10.1111/ j.1467-8373.2012.01491.x

Lenz A, Olinto MTA, Dias-da-Costa JS, Alves AL, Balbinotti M, Pattussi MP, Bassani DG (2009) Socioeconomic, demographic and lifestyle factors associated with dietary patterns of women living in Southern Brazil. Cadernos de saude publica 25:1297-1306

Lwasa S, Mugagga F, Wahab B, Simon D, Connors J, Griffith C (2014) Urban and peri-urban agriculture and forestry: transcending poverty alleviation to climate change mitigation and adaptation. Urban Clim 7:92-106. https://doi.org/10.1016/j.uclim.2013.10.007

Mirmiran P, Mohammadi F, Allahverdian S, Azizi F (2002) Association of educational level and marital status with dietary intake and cardiovascular risk factors in Tehranian adults: Tehran lipid and glucose study (TLGS). Nutr Res 22(12):1365-1375. https://doi.org/10.1016/S02715317(02)00440-2

Map of Lae (n.d.) From: http://www.justmaps.org/maps/images/papua/lae-map1.gif

Mueller I, Vounatsou P, Allen BJ, Smith T (2001) Spatial patterns of child growth in Papua New Guinea and their relation to environment, diet, socio-economic status and subsistence activities. Ann Human Biol 28(3):263-280. https://doi.org/10.1080/030144601300119089

Murakami K, Miyake Y, Sasaki S, Tanaka K, Ohya Y, Hirota Y (2009) Education, but not occupation or household income, is positively related to favorable dietary intake patterns in pregnant Japanese women: the Osaka maternal and child health study. Nutr Res 29(3):164-172. https://doi.org/10. 1016/j.nutres.2009.02.002

Nahuet P (2014) Perceived impact of village oil palm production on the livelihood of the growers in the Markham valley of Papua New Guinea (Ph.D.), Papua New Guinea University of Technology, Lae, PNG

Nahuet P, Bue V (2015) Perceived impact of village oil palm production on the livelihood of the growers in the Markham valley of Papua New Guinea. Niugini Agrisaiens 10:40-46

New Guinea Map (n.d.) From http://www.justmaps.org/maps/images/papua/lae-map1.gif 
Niles MT, Ahuja R, Esquivel MJ, Mango N, Duncan M, Heller M, Tirado C (2017) Climate change and food systems: assessing impacts and opportunities. Meridian Institute, Washington, DC

PNG National Statistical Office (2011) National population and housing census 2011. Government of Papua New Guinea

PNG National Weather Service (2019) PNG national weather service. Retrieved 01 Apr 2019. http:// www.pngmet.gov.pg/

Rauff KO, Bello R (2015) A review of crop growth simulation models as tools for agricultural meteorology. Agric Sci 6:1098-1105. https://doi.org/10.4236/as.2015.6910

Rezazadeh A, Rashidkhani B, Omidvar N (2010) Association of major dietary patterns with socioeconomic and lifestyle factors of adult women living in Tehran, Iran. Nutrition 26(3):337-341. https://doi.org/10.1016/j.nut.2009.06.019

Rodgers AB (2015) Scientific report of the 2015 dietary guideline advisory committee: advisory report to the secretary of health and human service and the secretary of agriculture. U.S department of agriculture and Department of Health and Human Services, Washington, DC

Rosegrant MW, Valmonte-Santos R, Thomas T, You L, Chiang C (2015) Climate change, food security, and socioeconomic livelihood in Pacific Island countries. Asian Development Bank and International Food Policy Research Institute, Mandaluyong City, Philippines

Sahn DE, Alderman H (1997) On the determinants of nutrition in Mozambique: the importance of age-specific effects. World Dev 25(4):577-588

Savy M, Martin-Prével Y, Traissac P, Delpeuch F (2007) Measuring dietary diversity in rural Burkina Faso: comparison of a 1-day and a 3-day dietary recall. Public Health Nutr 10(1):71-78. https:// doi.org/10.1017/S1368980007219627

Schmidt E, Gilbert R, Holtemeyer B, Rosenbach G, Benson T (2019) Papua New Guinea survey report: rural household survey on food systems

Shack KW, Grivetti LE, Dewey KG (1990) Cash cropping, subsistence agriculture, and nutritional status among mothers and children in lowland Papua New Guinea. Soc Sci Med 31(1):61-68. https://doi.org/10.1016/0277-9536(90)90010-P

SPREP (n.d.) Pacific adaptation to climate change, Papua New Guinea: Report od In-Country consultation. Retrieved from: https://www.sprep.org/attachments/Climate_Change/PACC_Report_ of_in-country_consultations_Nauru.pdf

Swindale A, Bilinsky P (2006) Household dietary diversity score (HDDS) for measurement of household food access: indicator guide. Food and Nutrition Technical Assistance Project, Academy for Educational Development, Washington, DC

Tapulu W, Jana KS, Sekae T (2014) Change detection study of Lae Urban. The second largest city of Papua New Guinea using multi-temporal high resolution remote sensing data. Int J Manage Soc Sci Res (IJMSSR) 3(10). ISSN: 23319-4421

Tarutia R (2019) Map of West Taraka, Lae, Morobe Province. DroneTree Mapping and Solutions, Lae (Papua New Guinea)

Taylor M, McGregor A, Dawson B (2016) Vulnerability of Pacific Island agriculture and forestry to climate change. Pacific Community (SPC), Noumea, New Caledonia

Thorne-Lyman AL, Valpiani N, de Pee S, Bloem MW, Sun K, Semba RD, Sari M (2009) Household dietary diversity and food expenditures are closely linked in Rural Bangladesh, increasing the risk of malnutrition due to the financial crisis. J Nutr 140(1):182S-188S. https://doi.org/10.3945/ jn.109.110809

Torheim LE, Ouattara F, Diarra MM, Thiam FD, Barikmo I, Hatløy A, Oshaug A (2004) Nutrient adequacy and dietary diversity in rural Mali: association and determinants. Eur J Clin Nutr 58:594. https://doi.org/10.1038/sj.ejcn.1601853

Umezaki M, Ohtsuka R (2003) Adaptive strategies of highlands-origin migrant settlers in Port Moresby, Papua New Guinea. Human Ecol 31(1):3-25. https://doi.org/10.1023/A: 1022881506510

United Nations Population Fund (2007) State of the world population: unleashing the potential of urban growth. United Nations Population Fund, New York 
UN DESA (2018) World Urbanization prospects: the 2018 revision (dataset). Retrieved from: https:// esa.un.org/unpd/wup/Download/

UNDP (2018) Human development indices and indicators-2018 statistical update. United Nations Development Programme, New York

Vandevijvere S, De Vriese S, Huybrechts I, Moreau M, Van Oyen H (2010) Overall and within-food group diversity are associated with dietary quality in Belgium. Public Health Nutr 13(12):19651973

Wairiu M, Lal M, Iese V (2012) Climate change implications for crop production in Pacific Islands region. Food production-approaches, challenges and tasks. IntechOpen, London

Walsh BJ (1987) The growth and development of squatter settlements in Lae, Papua New Guinea. In: Mason L, Hereniko P (eds) In search of a home. Institute of Pacific Studies of the University of the South Pacific, Suva

Weber EH (2014) Climate change, agriculture and food security in the Pacific Islands. J South Pac Agric 20

WHO (2003) Diet, food supply and obesity in the Pacific. World Health Organization, Geneva

World Climate Guide (2019) Tabubil climate guide, Papua New Guinea. Retrieved 01 Apr 2019. http://www.worldclimateguide.co.uk/guides/papua-new-guinea/tabubil/

Yamauchi T, Umezaki M, Ohtsuka R (2001) Influence of urbanisation on physical activity and dietary changes in Huli-speaking population: a comparative study of village dwellers and migrants in urban settlements. Br J Nutr 85(1):65-73. https://doi.org/10.1079/BJN2000208 